\title{
Efforts to Improve Mathematics Learning Outcomes in Class III Materials for Measurement of Time Units at SDN Pende 03 Using Analog Clock
}

\section{Rizki Rahmawati}

SD Negeri Pende 03

qiequadratz@gmail.com

\section{Article History}

received 3/12/2020

revised $17 / 12 / 2020$

accepted 31/12/2020

\begin{abstract}
This research was carried out with the aim of improving the mathematics learning outcomes of third grade students at SDN Pende 03 by using analog clock teaching aids on time unit measurement material. This type of research is classroom action research (CAR). The subjects were class III students, totaling 23 students. This CAR design includes planning, implementation, observation (evaluation), and reflection. Data collection techniques using observation, tests, and documentation. Data analysis used quantitative descriptive statistics. The results showed an increase in the percentage of student learning outcomes, this can be seen from each cycle. It was found that student learning outcomes increased compared to the pre-cycle average score of 51.96 to 63.48 in the first cycle, then to 72.17 in the second cycle. Thus, it can be concluded that the use of analog clock teaching aids in time unit measurement material can improve student learning outcomes.
\end{abstract}

Keywords: learning outcomes, mathematics, teaching aids, elementary school

\begin{abstract}
Abstrak
Penelitian ini dilaksanakan dengan tujuan untuk meningkatkan hasil belajar matematika peserta didik kelas III SDN Pende 03 dengan alat peraga jam analog pada materi pengukuran satuan waktu. Jenis penelitian ini adalah penelitian tindakan kelas (PTK). Subjeknya adalah peserta didik kelas III yang berjumlah 23 peserta didik. Desain PTK ini meliputi perencanaan, pelaksanaan, pengamatan (evaluasi), serta refleksi. Teknik pengumpulan data menggunakan observasi, tes, dan dokumentasi. Analisis data yang digunakan statistik deskriptif kuantitatif. Hasil penelitian menunjukkan adanya peningkatan persentase hasil belajar peserta didik, hal ini dapat dilihat dari setiap siklus. Didapatkan hasil belajar peserta didik meningkat dibanding nilai rata-rata pra siklus 51,96 menjadi 63,48 pada siklus I, kemudian menjadi 72,17 pada siklus II. Dengan demikian dapat disimpulkan bahwa penggunaan alat peraga jam analog pada materi pengukuran satuan waktu dapat meningkatkan hasil belajar peserta didik.
\end{abstract}

Kata Kunci : hasil belajar, matematika, alat peraga, sekolah dasar

Social, Humanities, and Education Studies (SHEs): Conference Series https://jurnal.uns.ac.id/shes

p-ISSN 2620-9284

e-ISSN 2620-9292 


\section{PENDAHULUAN}

Matematika merupakan muatan pembelajaran yang wajib ada di setiap jenjang pendidikan. Mulai dari anak SD sampai SMA bahkan di perguruan tinggi matematika menjadi salah satu mata pelajaran yang harus dikuasai oleh setiap peserta didik. Matematika adalah mata pelajaran tentang ilmu hitung yang tentunya sangat berhubungan dengan angka.

Menurut Gatot Muhsetyo (2015 : 1.26) Pembelajaran Matematika adalah proses pemberian pengalaman belajar kepada peserta didik melalui serangkaian kegiatan yang terencana sehingga peserta didik memperoleh kompetensi tentang bahan matematika yang dipelajari. Sedangkan manurut Ahmad Susanto (2013:186) Pembelajaran matematika adala suatu proses belajar mengajar yang dibangun oleh guru unruk mengembangkan kreativitas berpikir siswa yang dapat meningkatkan kemampuan berpikir siswa, serta dapat meningkatkan kemampuan mengkrontruksi pengetahuan baru sebagai upaya meningkatkan penguasaan yang baik terhadap materi matematika.

Salah satu karakteristik matematika adalah sebagai studi dengan objek kajian yang bersifat abstrak. Sifat abstrak ini tentu dirasa sulit untuk dicerna peserta didik, terutama pada tingkat sekolah dasar yang masih berada dalam tahap operasional konkret. Guru perlu berhati-hati dalam menanamkan konsep - konsep matematika pada peserta didik. Di satu sisi peserta didik SD pola berpikirnya masih terbatas pada benda-benda nyata, sedangkan di sisi lain objek-objek pada konsep matematika bersifat abstrak. Oleh karena itu, kegiatan pembelajaran matematika di SD haruslah disesuaikan dengan kegidupan peserta didik. Kegiatan pembelajaran matematika yang tidak terkait dengan konteks kehidupan peserta didik akan dirasa kurang bermakna, kurang menarik, dan sulit di pahami peserta didik.

Pembelajaran matematika yang membutuhkan pemikiran abstrak salah satunya adalah materi pengukuran waktu, bentuk materi tentang pengukuran waktu diantaranya menentukan letak jarum jam, membaca dan menuliskan tanda waktu jam dan menggunakan waktu dalam kehidupan sehari-hari. Kemampuan pengukuran waktu menjadi penting karena kemampuan tersebut sangat diperlukan dalam kehidupan sehari-hari seperti mengatur, membiasakan peserta didik untuk disiplin menggunakan waktu sebaik mungkin dan mengembangkanya sampai dewasa. Prasyarat yang perlu dimiliki oleh peserta didik sebelum memahami tentang pengukuran waktu yakni pemaham tentang konsep waktu seperti besok, sekarang, tadi, nanti, konsep pagi, siang dan malam. Beberapa prasyarat tersebut digunakan untuk memahami pengukuran waktu.

Selama ini kegiatan pembelajaran yang mendominasi kelas-kelas matematika adalah pada penekanan transfer ilmu dan latihan. Guru mendominasi kegiatan di kelas dan berfungsi sebagai sumber belajar utama. Guru menyajikan pengetahuan dan konsep matematika kepada peserta didik, peserta didik memperhatikan penjelasan guru dan contoh yang diberikan, kemudian peserta didik ditugaskan untuk menyelsaikan soal-soal sejenis yang diberikan guru. Kegiatan pembelajaran matematika hanya berkutat pada hal-hal tersebut. Pembelajaran matematika masih jarang dikaitkan dengan konteks kehidupan peserta didik sehari-hari.

Kegagalan guru dalam menyampaikan suatu pokok bahasan disebabkan pula saat proses belajar mengajar guru kurang membangkitkan perhatian dan aktivitas peserta didik dalam mengikuti pelajaran. Pelajaran matematika masih berorientasi pada pengembangan aspek kognitif yang mentrasnfer pengetahuan dari guru ke peserta didik yang diikuti dengan latihan - latihan untuk membantuk kemampuan sesaat. Metode yang digunakan cenderung masih menggunakan metode konvensional satu arah. Metode pembelajaran yang bervariatif juga masih kurang dikembangkan sehingga peserta didik cenderung pasif dalam pembelajaran di kelas. Hal tersebut merupakan beberapa penyebab dari rendahnya hasil belajar peserta didik. 
Menurut Oemar Hamalik (dalam Rusman 2012: 123) mengatakan: "Hasil belajar itu dapat terlihat dari terjadinya perubahan dari persepsi dan perilaku, termasuk juga perbaikan perilaku".

Menurut pendapat Munandi (dalam Rusman, 2012: 124) faktor yang mempengaruhi hasil belajar meliputi faktor internal dan faktor eksternal, yaitu : 1) Faktor Internal, yaitu a) Faktor fisiologis, kondisi kesehatan yang prima, tidak dalam keadaan lelah dan capek, tidak dalam keadaan cacat jasmani, dan sebagainya b) Faktor psikologis, meliputi intelegensi (IQ), perhatian, minat, bakat, motif, motivasi, kognitif, dan daya nalar siswa. 2) Faktor Eksternal yaitu : a) Faktor lingkungan, meliputi lingkungan fisik dan lingkungan sosial misalnya suhu, kelembaban, dan lainlain, b) Faktor instrumental, yaitu berupa kurikulum, sarana, dan guru.

Hasil belajar terbagi kedalam beberapa jenis, Benyamin Bloom (dalam Nana Sudjana, 2013: 22-23) mengkasifikasikan jenis-jenis hasil belajar menjadi tiga ranah, yaitu : ranah kognitif, afektif dan psikomotoris. Ranah kognitif berkenaan dengan hasil belajar intelektual, ranah afektif berkenaan dengan sikap dan ranah psikomotoris berkenaan dengan hasil belajar keterampilan.

Untuk menjadi peserta didik yang berkompeten, setiap peserta didik mengikuti proses pendidikan berupa pembelajaran. Dalam proses pembelajaran terdapat serangkaian kegiatan untuk memberikan pengalaman belajar yang berkaitan dengan pengetahuan, keterampilan, dan sikap. Proses merupakan faktor penting untuk memperoleh hasil yang baik dan memuaskan (Gatot Muhsetyo, 2015: 1.24).

Suatu pembelajaran akan lebih efektif apabila didukung dengan alat peraga atau media pembelajaran, dikarenakan alat peraga merupakan alat bantu yang digunakan guru ketika mengajar untuk membantu memperjelas materi pelajaran yang disampaikan kepada peserta didik dan mencegah terjadinya verbalisme pada diri sasaran pendidikan. Dengan pembelajaran yang kreatif dan menarik serta mampu membetuk konsep secara tepat, seorang guru juga akan dapat menarik dan membuat peserta didik lebih berminat untuk mengikuti pembelajaran yang selama ini dianggap membosankan dan sulit oleh peserta didik. Karena di dalam pembelajaran yang menyenangkan dan tepat akan membuat tujuan pembelajaran yang telah ditetapkan menjadi mudah tercapai.

Kata media berasal dari bahasa latin medius yang secara harfiah berarti tengah, perantara atau pengantar. Dalam bahasa Arab media adalah perantara atau pengantar pesan dari pengirim kepada penerima pesan (Azhar Arsyad, 2011:3). Menurut Gerlach dan Ely yang dikutip oleh Azhar Arsyad (2011), media apabila dipahami secara garis besar adalah manusia, materi dan kejadian yang membangun kondisi yang membuat siswa mampu memperoleh pengetahuan, ketrampilan atau sikap. Dalam pengertian ini, guru, buku teks, dan lingkungan sekolah merupakan media. Sedangkan menurut Criticos yang dikutip oleh Daryanto (2011:4) media merupakan salah satu komponen komunikasi, yaitu sebagai pembawa pesan dari komunikator menuju komunikan.

Menurut Arif S. Sadiman, dkk (2011) menyebutkan bahwa kegunaan-kegunaan media pembelajaran yaitu: a) Memperjelas penyajian pesan agar tidak terlalu bersifat verbalistis. b) Mengatasi keterbatasan ruang, waktu dan daya indera. c) Penggunaan media pembelajaran yang tepat dan bervariasi dapat mengatasi sikap pasif anak didik. d) Memberikan perangsang belajar yang sama. e) Menyamakan pengalaman. f) Menimbulkan persepsi yang sama.

Berpijak pada permasalahan yang telah diuraikan diatas, maka kiranya perlu diadakan suatu penelitian tindakan kelas (PTK), dalam hal ini penulis mengangkat judul "Upaya Meningkatkan Hasil Belajar Matematika Materi Pengukuran Satuan Waktu Kelas III SDN Pende 03 Dengan Alat Peraga Jam Analog" 


\section{METODE}

Pada penelitian ini menggunakan desain penelitian tindakan kelas. Menurut pendapat Suharsimi (2011:3) penelitian tindakan kelas merupakan suatu pencermatan terhadap kegiatan belajar berupa sebuah tindakan, yang sengaja diumculkan dan terjadi dalam sebuah kelas secara bersama. Penelitian tindakan kelas itu sendiri mengharuskan guru untuk selalu berusaha melakukan tindakan pembaharuan (inovasi) dalam proses belajar mengajar. Subjek dalam penelitian ini adalah peserta didik kelas III SD Negeri Pende 03. Dengan jumlah peserta didik sebanyak 23 peserta didik yang terdiri dari 9 peserta didik laki-laki dan 14 peserta didik perempuan. Objek penelitian ini adalah materi Matematika mengenai pengukuran satuan waktu. Dalam pelaksanaannya masing-masing siklus melalui empat tahapan, yakni : tahap perencanaan, tahap pelaksanaan, tahap pengumpulan data dan tahap refleksi. Analisis data yang digunakan dalam penelitian ini adalah statistik deskriptif. Penelitian ini dilaksanakan pada peserta didik kelas III SD Negeri 2 Pende 03 Tahun Pelajaran 2020/2021. Siklus I dilaksanakan pada tanggal 17 November 2020. Siklus II dilaksanakan pada tanggal 23 November 2020. Teknik pengumpulan data yang dilakukan dengan observasi dan tes, baik pre test maupun post test.

\section{HASIL DAN PEMBAHASAN}

Penelitian tindakan kelas yang dilakukan melalui dua siklus ini dilakukan untuk mengetahui bagaimana peningkatan hasil belajar peserta didik materi pengukuran satuan waktu kelas III SD Negeri Pende 03. Pada tiap siklusnya terdiri dari satu tindakan yang diwujudkan dalam satu kali pertemuan pembelajaran yang lamanya $2 \mathrm{x}$ 35 menit. Kegiatan perbaikan pembelajaran dalam setiap siklusnya terdiri dari perencanaan yang meliputi menyusun rencana pelaksanaan pembelajaran (RPP), menyiapkan alat peraga (berupa gambar), membuat lembar evaluasi tes tertulis, menyiapkan lembar pengamatan, guru mengadakan evaluasi, guru menganalisis hasil evaluasi, guru mengadakan perbaikan pada peserta didik yang mendapat nilai kurang dari 65 dengan kembali mengerjakan soal latihan. Setelah perencanaan, dilakukanlah pelaksanaan perbaikan pembelajaran yang meliputi kegiatan awal, kegiatan inti, dan kegiatan akhir pembelajaran, serta tindak lanjut. Selanjutnya, pengamatan yaitu analisis terhadap hasil belajar yang sudah didapatkan untuk kemudian dilakukan refleksi yang bertujuan untuk menilai dan mengamati apa yang telah terjadi selama pembelajaran berlangsung untuk kemudian dilakukan perbaikan terhadap kekurangankekurangan yang ditemukan dalam proses pembelajaran.

Berdasarkan hasil evaluasi pra siklus, hasil belajar peserta didik masih kurang dalam pembelajaran tema Indahnya Persahabatan Sub Tema Sahabat Satwa Pembelajaran satu Muatan Pelajaran Matematika materi satuan waktu, guru masih menggunakan metode ceramah, tanya jawab serta pendekatan saintifik sehingga pembelajaran kurang menyenangkan. Berdasarkan pembelajaran pra siklus, hasil belajar peserta didik rendah. Nilai yang diperoleh jauh dari yang diharapkan. Nilai ratarata kelasnya hanya 51,96. Jika dilihat dari ketuntasan belajar peserta didik dari 23 jumlah peserta didik kelas III SD Negeri Pende 03 yang tuntas sebanyak 8 peserta didik atau $34,78 \%$ dan sebanyak 15 peserta didik atau $65,22 \%$ belum tuntas. Peneliti menganggap pelaksanaan pembelajaran Pra siklus ini belum memuaskan karena hampir semua peserta didik masih kesulitan dalam mengerjakan soal konversi waktu. Maka peneliti mengadakan perbaikan pembelajaran.

Pada siklus I belum menunjukan hasil yang memuaskan, kemampuan peserta didik memahami pembelajaran tema Indahnya Persahabatan Sub Tema Sahabat Satwa Muatan Pelajaran Matematika materi konversi waktu pada kelas III Semester 2 SD Negeri Pende 03 dengan menyaksikan video pembelajaran tentang waktu, diperoleh hasil belajar peserta didik terhadap materi pembelajaran kurang maksimal. Dari hasil tes diperoleh nilai ketuntasan pra siklus dengan rata-rata 51,96 dengan 
presentase siswa tuntas $34,78 \%$. Dan rata-rata nilai siklus I sebesar 63,48 dengan presentase siswa tuntas 60,87\%. Rata-rata Nilai ini belum mencapai KKM yang di tetapkan di kelas III SD Negeri Pende 03 Tahun Pelajaran 2020/2021 yaitu 65.

Tabel 1. Hasil Belajar Matematika Peserta Didik pada PraSiklus dan Siklus I

\begin{tabular}{clcc}
\hline No & \multicolumn{1}{c}{ Hasil Belajar Peserta Didik } & $\begin{array}{c}\text { Pra } \\
\text { Siklus }\end{array}$ & Siklus I \\
\hline 1 & Jumlah Nilai & 1195 & 1460 \\
2 & Rata2 & 51,96 & 63,48 \\
3 & Jml Siswa Tuntas & 8 & 14 \\
4 & Jml Siswa Belum Tuntas & 15 & 9 \\
5 & Presentase Siswa Tuntas (\%) & 34,78 & 60,87 \\
6 & Presentase Siswa Belum Tuntas (\%) & 65,22 & 39,13 \\
\hline
\end{tabular}

Berdasarkan data pada tabel 1 tersebut di atas, diketahui peserta didik kelas III SD Negeri Pende 03 yang memiliki nilai kurang dari KKM (Kriteria Ketuntasan Minimal) yakni pada pra siklus sebanyak 15 peserta didik (65,22\%) sedangkan peserta didik yang mencapai ketuntasan sebanyak 8 peserta didik (34,78\%), setelah dilakukan perbaikan pada siklus I dengan menggunakan alat peraga jam analog, peserta didik yang kurang dari KKM (Kriteria Ketuntasan Minimal) berkurang, diketahui siklus I sebanyak 9 peserta didik $(39,13 \%)$, sedangkan peserta didik yang telah mencapai ketuntasan sebanyak 14 peserta didik $(60,87 \%)$.

Berdasarkan uraian di atas dapat dijelaskan bahwa proses pembelajaran belum berhasil karena banyak peserta didik yang nilainya masih di bawah KKM yakni di bawah 65 dan tingkat ketuntasan hanya 60,87\% sedangkan proses pembelajaran dianggap berhasil apabila tingkat ketuntasan paling tidak mencapai $75 \%$.

Dalam pembelajaran Siklus I, peneliti menggunakan menggunakan alat peraga jam analog dianggap efektif sehingga berhasil meningkatkan hasil dan aktifitas belajar peserta didik. Hanya saja peserta didik belum terbiasa dan masih agak kesulitan beradaptasi menggunakan alat peraga jam analog. Untuk itu harus diadakan perbaikan pembelajaran dimana peneliti akan tetap menggunakan menggunakan alat peraga jam analog.

Sedangkan pada siklus II penguatan yang diperoleh adalah antusias peserta didik untuk mengikuti pembelajaran semakin meningkat, karena pembelajaran dengan menggunakan alat peraga jam analog, materi lebih mudah dipahami oleh peserta didik. Setelah diadakan penelitian pada siklus II menunjukan hasil bahwa kemampuan peserta didik dalam memahami materi pembelajaran menunjukan peningkatan. Pada siklus I peserta didik yang mendapat nilai sesuai dengan KKM hanya 14 peserta didik dari 23 peserta didik di SD Negeri Pende 03, sedangkan peserta didik yang lain mendapatkan dibawah KKM. Setelah diadakan perbaikan, terjadi peningkatan yang begitu cepat pada siklus II.

Hasil analisis terhadap ketercapaian indikator oleh peserta didik dalam perbaikan pembelajaran siklus II dapat dijelaskan sebagai berikut. Ketercapaian ratarata skor adalah 70,87 sedangkan KKM (Kriteria Ketuntasan Minimal) yang telah ditetapkan untuk Matematika adalah 65. Jadi skor rata-rata sudah di atas KKM. Jika dilihat dari ketuntasan belajar peserta didik dari 23 jumlah peserta didik kelas III SD Negeri Pende 03 yang telah tuntas sebanyak 19 peserta didik atau 82,61\% dan yang belum tuntas sebanyak 4 peserta didik atau $17,39 \%$.

Berdasarkan uraian di atas dapat dijelaskan bahwa proses pembelajaran telah berhasil karena banyak peserta didik yang nilainya sudah di atas KKM yakni di atas 70 
$\%$ dan tingkat ketuntasan mencapai $82,61 \%$. Proses pembelajaran dianggap berhasil apabila tingkat ketuntasan paling tidak mencapai $75 \%$.

Dalam perbaikan pembelajaran Siklus II, peneliti menggunakan alat peraga jam analog seperti pada siklus I dalam proses pembelajaran. Pembelajaran menggunakan alat peraga jam analog dianggap efektif dan berhasil meningkatkan hasil belajar peserta didik. Dalam perbaikan pembelajaran siklus II peserta didik lebih antusias karena mereka sebelumnya menggunakan alat peraga jam analog pada siklus I. Perbaikan pembelajaran siklus II dianggap berhasil walaupun masih ada 4 peserta didik yang nilainya masih di bawah KKM, sehingga diadakan remidial dan tidak perlu adanya perbaikan pembelajaran selanjutnya.

Adapun peningkatan hasil belajar peserta didik berdasarkan hasil tes siklus I dan siklus II sebagai berikut :

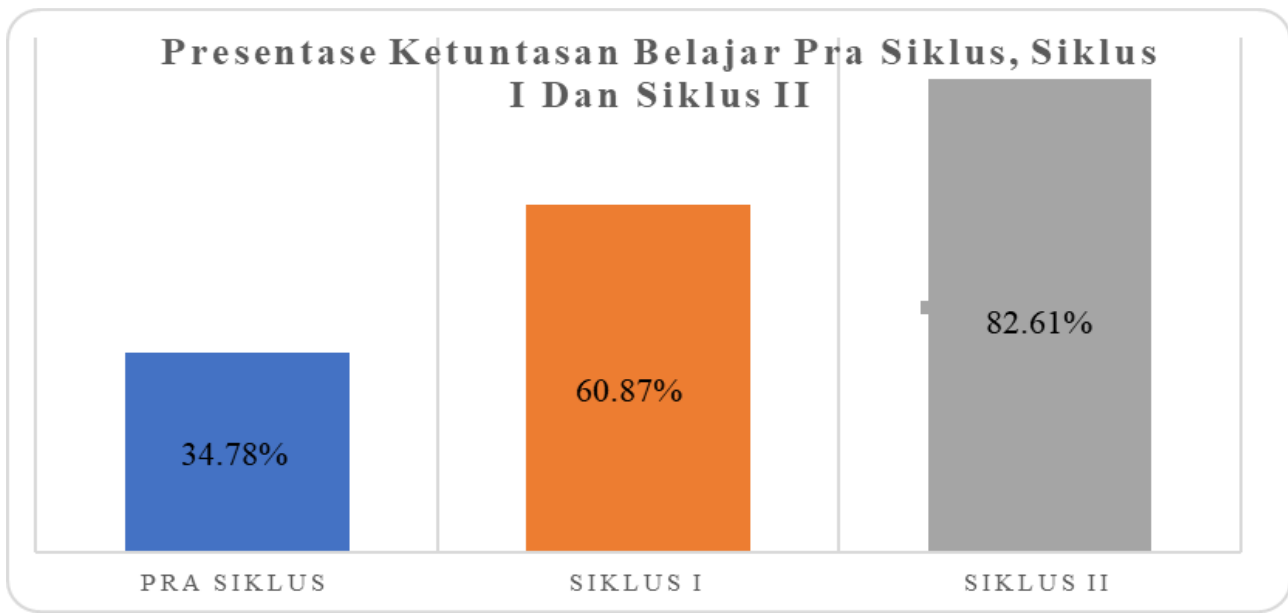

Gambar 1. Rekapitulasi Persentase Ketuntasan

Melalui hasil penelitian ini menunjukkan bahwa perbaikan pembelajaran melalui alat peraga jam analog memiliki dampak positif dalam meningkatkan hasil belajar peserta didik. Pada siklus 2 ketuntasan belajar peserta didik tercapai.Hasil dari penelitian ini menunjukkan bahwa penggunaan alat peraga jam analog pada materi pengukuran satuan waktu terbukti dapat meningkatkan hasil belajar peserta didik kelas III SD Negeri Pende 03 Kecamatan Kersana Kabupaten Brebes.

\section{SIMPULAN}

Berdasarkan pembahasan dan hasil penelitian maka dapat disimpulkan penggunaan alat peraga jam analog pada pembelajaran siklus II, ternyata sudah menunjukkan hasil yang maksimal. Hasil belajar yang diperoleh lebih baik dibandingkan pada saat pelaksanaan kegiatan pembelajaran Matematika pada siklus I. Hasil yang diperoleh semua peserta didik menunjukkan kemampuan akhir yang lebih baik dibandingkan dengan kemampuan awal sebelum tindakan. Dari hasil pelaksanaan perbaikan pembelajaran dan refleksi siklus II maka dapat disimpulkan bahwa pelaksanaan tindakan pembelajaran dengan menggunakan alat peraga jam analog untuk meningkatkan hasil belajar peserta didik pada materi pengukuran satuan waktu dapat diakhiri pada siklus II dengan hasil yang memuaskan.

Berdasarkan kesimpulan yang telah diambil melalui analisis data yang terkumpul, dirasa perlu menyampaikan saran-saran sebagai berikut: Bagi peserta didik, diharapkan dapat mengoptimalkan penggunaan alat peraga tersebut sehingga dapat meningkatkan pemahaman terhadap materi dan memotivasi peserta didik untuk memperoleh hasil belajar yang lebih baik. Bagi guru, dengan penggunaan alat peraga jam analog memberikan dampak positif pada hasil belajar peserta didik, guru 
diharapkan dapat meningkatkan profesionalisme yaitu dengan mengoptimalkan penggunaan alat peraga atau media pembelajaran dan meningkatkan pengajaran yang lebih baik.

\section{DAFTAR PUSTAKA}

Ahmad, Susanto. (2013). Teori Belajar dan Pembelajaran di Sekolah Dasar. Jakarta: Kencana Prenada Media Group

Arif S. Sadiman, dkk. (2011). Media Pendidikan, Pengertian, Pengembangan, dan Pemanfaatannya. Jakarta: PT. Raja Grafindo Persada.

Arikunto, Suharsimi, dkk. (2011). Penelitian Tindakan Kelas. Jakarta: PT Bumi Aksara. Arsyad, Azhar. (2011). Media Pembelajaran. Jakarta: Raja Grafindo Persada Daryanto. (2011) Media Pembelajaran. Bandung: Sarana Tutorial Nurani Sejahtera.

Muhsetyo, Gatot dkk. (2011). Pembelajaran Matematika SD. Jakarta : Universitas Terbuka.

Rusman. (2012). Belajar dan Pembelajaran Berbasis Komputer. Bandung: Alfabetha.

Sudjana, Nana. (2013). Dasar-Dasar Proses Belajar Mengajar. Bandung: Sinar Baru Algesindo. 